\title{
Carbon Monoxide Inhibits Cytokine and Chloride Secretion in Human Bronchial Epithelia
}

\author{
Rui-Gang Zhanga ${ }^{\mathrm{a} b} \quad$ Chung-Yin Yip ${ }^{\mathrm{b}}$ Wing-Hung Ko ${ }^{\mathrm{b}}$ \\ aDepartment of Physiology, Basic Medical School, Guangdong Medical University, Guangdong, bSchool \\ of Biomedical Sciences, The Chinese University of Hong Kong, N.T., Hong Kong, China
}

\section{Key Words}

Carbon monoxide $\cdot$ Anti-inflammatory $\cdot$ Purinergic signalling $\cdot$ Chloride secretion $•$ Calcium increase $\cdot$ Heme oxygenase

\begin{abstract}
Background/Aims: Carbon monoxide (CO) is an important gas produced endogenously by heme oxygenase $(\mathrm{HO})$ that functions as an anti-inflammatory and in ion channel modulation, but the effects of $\mathrm{CO}$ on airway inflammation and ion transport remains unclear. Methods: The effect of $\mathrm{CO}$ on cell damage- and nucleotide-induced pro-inflammatory cytokine release in primary human bronchial epithelia cells (HBE) and in the 16HBE140- human bronchial epithelial cell line were investigated. The effects of $\mathrm{CO}$ on calcium- and cAMP-dependent chloride $\left(\mathrm{Cl}^{-}\right)$ secretion were examined using a technique that allowed the simultaneous measurement and quantification of real-time changes in signalling molecules (CAMP and $\mathrm{Ca}^{2+}$ ) and ion transport in a polarised epithelium. Results: $C O$ suppressed the release of interleukin (IL)- 6 and IL- 8 and decreased the phosphorylation of ERK1/2 and NF-KB p65. Furthermore, CO inhibited UTP-induced increases in calcium and $\mathrm{Cl}^{-}$secretion, and forskolin-induced increases in CAMP and $\mathrm{Cl}^{-}$secretion. Conclusions: These findings suggest a novel anti-inflammatory role of $\mathrm{CO}$ in human bronchial epithelia via interactions with purinergic signalling pathways. Further, $\mathrm{CO}$ modulated both the $\mathrm{Ca}^{2+}$ - and cAMP-dependent secretion of $\mathrm{Cl}^{-}$.

(C) 2018 The Author(s)

Published by S. Karger AG, Basel
\end{abstract}

\section{Introduction}

Accumulating evidence suggests a protective role of carbon monoxide (CO), which is produced from the catabolism of heme via heme oxygenase (HO), in the lungs and many other organ systems. Although a phase I clinical trial examined the therapeutic potential of $\mathrm{CO}$ to treat airway diseases and to reduce acute, endotoxin-induced airway inflammation (NCT00094406), the mechanisms underlying the anti-inflammatory properties of CO and 


\section{Cellular Physiology Cell Physiol Biochem 2018;49:626-637 \begin{tabular}{l|l|l} 
DOI: 10.1159/000493026 & $\begin{array}{l}\text { O 2018 The Author(s). Published by S. Karger AG, Basel } \\
\text { www.karger.com/cpb }\end{array}$ \\
\hline
\end{tabular} \\ Zhang et al.: $\mathrm{CO}$ and Airway Secretion}

its potential modulatory effect on ion transport in human airway epithelia remain largely unknown.

Inflammation is associated with the extracellular release of nucleotides, and the subsequent activation of purinergic signalling can promote chronic inflammation [1]. Further, extracellular ATP could trigger and maintain asthmatic airway inflammation involving eosinophilia and the production of T-helper cell type 2 (Th2) cytokines, including IL-4 and IL-13 [2]. Pro-secretory epithelial ion transport is likewise observed in allergic airway inflammation [3-5]. In lung diseases characterised by impaired oxygen and $\mathrm{CO}_{2}$ transport, an increase in the airway surface liquid (ASL) height, which is often observed during lung inflammation, might further aggravate the symptoms [6]. Therefore, inhibiting purinergic receptor-induced intracellular signals and/or electrolyte transport functions could represent a new therapeutic strategy for airway inflammation.

Previously, we reported that bronchial epithelial damage due to poly-L-arginine (PLA), a surrogate that mimics the effects of eosinophil-derived major basic protein, causes the release of nucleotides and the subsequent activation of p38 and ERK1/2 mitogen-activated protein kinase (MAPK) and NF- $\kappa$ B signalling [7]. The pro-inflammatory cytokines IL-6 and IL-8 are released towards the apical compartment following the exposure of airway epithelial cells to PLA [8]. Accordingly, we examined the effects of CO on cell damage- and nucleotideinduced pro-inflammatory signalling pathway activation and calcium- and cAMP-dependent $\mathrm{Cl}^{-}$secretion.

\section{Materials and Methods}

\section{Reagents}

ATP $\gamma$ S, tin protoporphyrin IX (SnPP), and 3, 4,5-Trimethoxy-N-(2-methoxyethyl)-N-(4-phenyl-2thiazolyl)benzamide (Eact) were purchased from Tocris (Bristol, UK). Poly-L-arginine, UTP, forskolin, hemin, haemoglobin, myoglobin, tricarbonyldichlororuthenium (II) dimer (CORM-2), tricarbonylchloro(glycinato) ruthenium (II) (CORM-3) were obtained from Sigma (St Louis, MO, USA). Inactive CORM (iCORM) was prepared by adding the compound to $\mathrm{H}_{2} \mathrm{O}$ and leaving it overnight to liberate $\mathrm{CO}$. All cell culture reagents were obtained from Invitrogen (Carlsbad, CA, USA) unless otherwise stated.

\section{Cell culture}

The human 16HBE14o- bronchial epithelia cell line was cultured and maintained as previously described [9]. Primary human bronchial epithelial (HBE) cells were obtained from ScienCell Research Laboratories (Carlsbad, CA, USA) and maintained in Bronchial Epithelial Cell Medium (ScienCell Research Laboratories, USA) as described previously [7, 10]. To simultaneously measure intracellular calcium concentration $\left(\left[\mathrm{Ca}^{2+}\right]_{\mathrm{i}}\right)$ and short-circuit current $\left(I_{S C}\right)$ or intracellular cAMP levels and $I_{S C}$, the cells were seeded onto $0.4 \mu \mathrm{m}$ pore Transwell ${ }^{\circledR}$-COL membranes (culture area $0.1 \mathrm{~cm}^{2}$; Costar, Cambridge, MA). The cells reached confluence after 10 days with a resistance greater than $300 \Omega \cdot \mathrm{cm}^{2}$.

\section{ELISA}

The cells were grown in 24-well culture plates and cell-free supernatants were collected from control and treated cells and analysed using a commercially available ELISA specific for IL-6 (eBioscience, San Diego, USA) and IL-8 (BD Biosciences, San Diego, USA) according to the manufacturers' protocols. All experiments were performed in duplicate. For some experiments, cells were grown the air-liquid interface on Transwell@-COL inserts in a 6-well plate and apical and basolateral media were collected for quantification of polarised IL-6 and IL-8 release [8].

\section{Small interference RNA transfection}

The knockdown of HO-1 by small interference RNA (siRNA) was performed as previously described [11]. Briefly, the medium was changed to OPTI-MEM ${ }^{\mathrm{TM}}$ I Reduced Serum Medium (Gibco, Invitrogen Corporation, USA) after cells reached 70\%-80\% confluence. Transfection was achieved using 25 nM siRNA (Ambion, Austin, TX, USA) and Lipofectamine ${ }^{\circledR}$ RNAiMAX Reagent (Invitrogen) 2 hours before hemin was added. 


\section{Cellular Physiology Cell Physiol Biochem 2018;49:626-637 \begin{tabular}{l|l|l} 
DOI: 10.1159/000493026 & $\begin{array}{l}\text { O 2018 The Author(s). Published by S. Karger AG, Basel } \\
\text { www.karger.com/cpb }\end{array}$
\end{tabular}}

Zhang et al.: $\mathrm{CO}$ and Airway Secretion

The cells were treated with hemin $(10 \mu \mathrm{M})$ for 6 hours for Western blotting analysis to verify knockdown efficacy. For the ELISAs, the cells were stimulated with PLA, ATP $\gamma$ S, or UTP for 3 hours. The HO- 1 siRNA was a 21-basepair duplex (CCUCAAAUGCAGUAUUUUUtt) and the mock-transfection was performed using only the transfection reagent.

\section{Western blotting}

SDS-PAGE (Bio-Rad, CA, USA) followed by transfer to polyvinylidene fluoride (PVDF) membranes (Immobilon-P, Millipore Corporation, Billerica, MA) was performed as previously described [10]. The antiphospho-p44/42 MAPK (ERK 1/2; Cell Signaling Technology; Beverly, MA; 1:1, 000), anti-p44/42 MAPK (ERK 1/2; Cell Signaling Technology; 1:1, 000), anti-phospho-p65 NF-кB (Cell Signaling Technology; 1:1, 000), anti-p65 NF-кB (Cell Signaling Technology; 1:1, 000), anti- $\beta$-actin (Cell Signaling Technology; 1:1, 000), anti-HO-1 (Abcam, Cambridge, UK; 1:2000), and anti-HO-2 (Abcam; 1:2000) primary antibodies were used.

\section{RT-PCR}

Total RNA was extracted using TRIzol ${ }^{\mathrm{TM}}$ Reagent (Invitrogen) and reverse transcribed to cDNA using iScript $^{\mathrm{TM}}$ Reverse Transcription Supermix (Bio-Rad Laboratories, Hercules, USA). RT-PCR was performed using TaKaRa Taq ${ }^{\mathrm{TM}}$ DNA polymerase, and the products were separated on a $2.5 \%$ agarose gel. The sequences for the RT-PCR primers were: ho-1: (5'-3') attctcttggctggcttcct and (3'-5') attctcttggctggcttcct; ho-2: (5'$\left.3^{\prime}\right)$ ccagaggagcgagagcag and ( $\left.3^{\prime}-5^{\prime}\right)$ ccgagaggtcagccattc; and gapdh: (5'-3') cgctctctgctcctcctgtt and ( $\left.3^{\prime}-5^{\prime}\right)$ ccatggtgtctgagcgatgt.

Simultaneous measurements of $\left[\mathrm{Ca}^{2+}\right]_{i}$ and $I_{S C}$

UTP-induced calcium signals and anion secretion were examined simultaneously in polarised 16HBE14o- cells as previously described [9]. Briefly, cells were loaded with $3 \mu \mathrm{M}$ fura-2/AM (Invitrogen) and $1.6 \mu \mathrm{M}$ pluronic $\mathrm{F} 127$ (Invitrogen) for $45 \mathrm{~min}$ at $37^{\circ} \mathrm{C}$. The cells were transferred to a miniature Ussing chamber mounted on an inverted microscope (Olympus IX70, Center Valley, PA, USA) equipped with a 20× water immersion objective (numerical aperture 0.6). A basolateral to apical $\mathrm{Cl}^{-}$gradient was applied across the monolayers by replacing the apical Krebs- Henseleit (KH) solution (117 mM NaCl, $25 \mathrm{mM} \mathrm{NaHCO}, 4.7$ $\mathrm{mM} \mathrm{KCl}, 1.2 \mathrm{mM} \mathrm{MgCl}, 1.2 \mathrm{mM} \mathrm{KH}_{2} \mathrm{PO}_{4}, 2.5 \mathrm{mM} \mathrm{CaCl}_{2}$, and $11 \mathrm{mM}$ D-glucose, $\mathrm{pH} 7.4$ when equilibrated with $5 \% \mathrm{CO}_{2}-95 \% \mathrm{O}_{2}$ ) with a reduced $\mathrm{Cl}^{-}$concentration solution $\left(\mathrm{NaCl}, \mathrm{KCl}, \mathrm{CaCl}_{2}\right.$, and $\mathrm{MgCl}_{2}$ replaced with Na-gluconate, K-gluconate, Ca-gluconate, and $\mathrm{MgSO}_{4}$, respectively) to generate a favourable gradient for $\mathrm{Cl}^{-}$ exit [12]. The cells were excited at $340 \mathrm{~nm}$ and $380 \mathrm{~nm}$ and Fura-2 ratios ( $>510 \mathrm{~nm}$ ) were recorded using a scientific CMOS camera (pco.edge 5.5; PCO AG, Kelheim, Germany) to measure changes in $\left[\mathrm{Ca}^{2+}\right]_{\mathrm{i}^{*}}$ The $I_{S C}$ was simultaneously measured using a voltage-clamp amplifier (VCC 600; Physiologic Instruments, San Diego, CA, USA). A $1 \mathrm{mV}$ transepithelial potential difference (p.d.) was applied periodically and the change in current was used to calculate the transepithelial resistance using Ohm's law. The signals were digitised and recorded with the MetaFluor Imaging Software (v.7.5 with FRET module). The effects of CO-releasing molecules (CORMs) or CO on UTP-induced calcium and $I_{S C}$ changes were examined by perfusing the apical aspect of the epithelia with CORMs or CO-containing solution for $10 \mathrm{~min}$ before the addition of UTP.

\section{Simultaneous measurements of cAMP and $I_{S C}$}

Real-time cAMP levels were measured as previously described [10]. Briefly, cells grown on Transwell@COL membranes were transfected with the Epac-based cAMP sensor CFP-Epac-YFP and excited at $436 \mathrm{~nm}$. CFP and YFP images were simultaneously recorded using an imaging setup equipped with a Photometrics $\mathrm{DV}^{2}$ emission splitting system (Photometrics, Tucson, USA) with two emission filters (470/30 nm for CFP; $535 / 30 \mathrm{~nm}$ for FRET). The fluorescence images were background subtracted, and real-time cAMP changes were represented by a normalised CFP/ FRET emission ratio. The $I_{S C}$ was simultaneously measured and recorded as described above.

Preparation of CO-containing solution

CO gas (99.99\%) was purchased from Guangdong Huate Gas Co., Ltd (Guangdong, China). Low $\mathrm{Cl}^{-} \mathrm{KH}$ solution ( $50 \mathrm{ml}$ ) was bubbled with $\mathrm{CO}$ in a glass bottle for $30 \mathrm{~min}$ [13]. Different dilutions were achieved by mixing the bubbled low $\mathrm{Cl}^{-} \mathrm{KH}$ solution with non-bubbled low $\mathrm{Cl}^{-} \mathrm{KH}$ solution. 


\section{Cellular Physiology Cell Physiol Biochem 2018;49:626-637 \begin{tabular}{ll|l} 
and Biochemistry Published online: 30 August, 2018 & $\begin{array}{l}\text { (c) } 2018 \text { The Author(s). Published by S. Karger AG, Basel } \\
\text { www.karger.com/cpb }\end{array}$ \\
\hline
\end{tabular}}

Zhang et al.: $\mathrm{CO}$ and Airway Secretion

\section{CO quantification}

The quantification of $\mathrm{CO}$ from CORMs and CO-bubbled low $\mathrm{Cl}^{-} \mathrm{KH}$ solution was assessed spectrophotometrically by measuring the conversion of deoxymyoglobin to carbonmonoxy-myoglobin as previously described [14]. Briefly, deoxymyoglobin solutions $(50 \mu \mathrm{M})$ were freshly prepared by dissolving myoglobin in $0.04 \mathrm{M}$ phosphate buffer ( $\mathrm{pH} 6.8$ ) in the presence of $0.1 \%$ sodium dithionite. CORM-2 and CORM-3 were prepared in stock solution ( $5 \mathrm{mM}$ ) and solubilised in DMSO and water, respectively. Different volumes of the CORMs $(0.33,1,3,9,20 \mu \mathrm{L})$ were added to $1 \mathrm{ml}$ of the deoxymyoglobin solutions. For the quantification of $\mathrm{CO}$ in $\mathrm{CO}$-bubbled low $\mathrm{Cl}^{-} \mathrm{KH}$ solution, the bubbled $\mathrm{KH}$ solution was diluted and the same volume $(10 \mu \mathrm{L})$ of the $\mathrm{KH}$ solution was added to the deoxymyoglobin solutions. The absorption spectrum and absorbance $(540 \mathrm{~nm})$ were determined using a New Molecular Devices SpectraMax i3 plate reader (Molecular Devices, USA).

\section{HO activity assay}

HO enzyme activity was measured as previously described [15]. Briefly, the cells were harvested in 0.1 $\mathrm{M}$ phosphate buffer containing $2 \mathrm{mM} \mathrm{MgCl}_{2}$ and disrupted by three cycles of freezing and thawing followed by sonication on ice. The samples were then centrifuged at $15000 \times g$ for $15 \mathrm{~min}$ and the supernatant was added to the reaction mixture containing NADPH (1 mM), rat liver cytosol as a source of biliverdin reductase ( $3 \mathrm{mg}$ protein, prepared from $105000 \mathrm{~g}$ supernatant fraction), and the substrate hemin $(100 \mu \mathrm{M})$. The reaction was carried out in the dark for one hour at $37^{\circ} \mathrm{C}$ and terminated by the addition of chloroform. The extracted bilirubin was determined by calculating the difference in absorbance between 464 and $530 \mathrm{~nm}$ using a New Molecular Devices SpectraMax i3 plate reader (Molecular Devices, USA).

\section{Statistical analysis}

Data were expressed as means \pm standard errors (S.E.). Experimentally induced changes in the Fura-2 fluorescence ratio, FRET ratio, and $I_{S C}$ were quantified by measuring each parameter at the peak of a response and subtracting the equivalent values measured immediately prior to stimulation. Comparisons between control and treated epithelia were performed using one-way ANOVA with either Tukey's or Dunnett's post hoc test (GraphPad Prism 5).

\section{Results}

\section{Expression of HO-1 and HO-2 in HBE cells}

The expression of ho- 1 and ho- 2 was examined in 16HBE14o- cells (Fig. 1a). Consistent with a previous report on primary human airway epithelial cells, the relative expression of ho-2 (0.76 \pm 0.07) was higher than ho-1 (0.19 \pm 0.03$)$ (Fig. 1c) [16]. The expression of H0-1 and HO-2 were examined in 16HBE140- and primary HBE cells. HO-2 was highly expressed

Fig. 1. Expression of HO-1 and HO2. a) Electrophoresis of the ho-1 and ho-2 RT-PCR products. Lane 1: negative control; lane 2: ho-1 PCR product (96 bp); lane 3: ho-2 PCR product (142); lane 4: gapdh housekeeping PCR product (173 bp); lane 5: DNA marker. b) Expression of HO-1 and HO-2 was examined in both primary HBE (left) and 16HBE14o- (right). Beta-actin was used as the housekeeping protein. c) and d) Summarized data for ho-1 and ho-2 mRNA expression (c) and protein expression (d) level in primary HBE and 16HBE140- cells. Each column represents the mean \pm S.E. $n=3-4$.

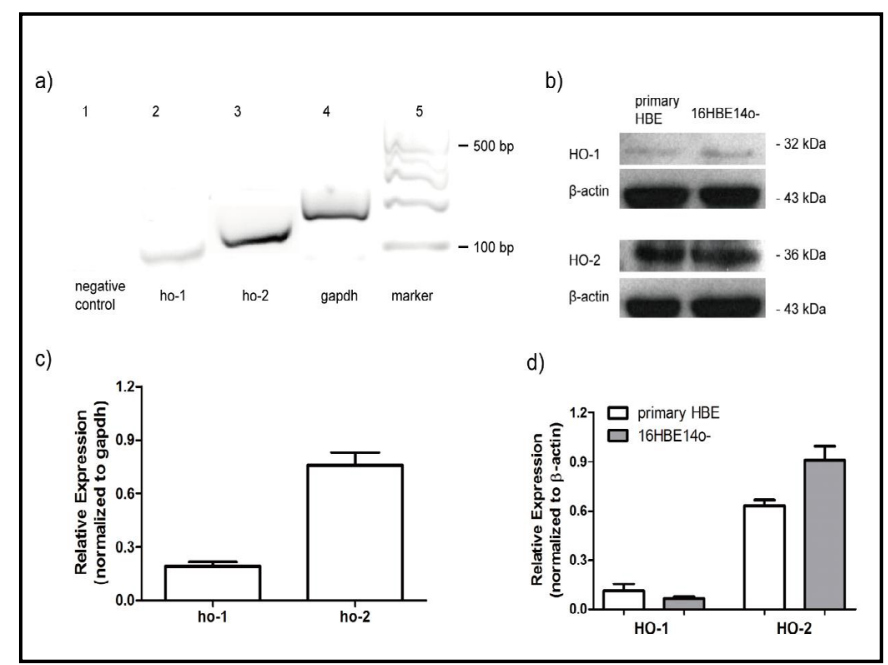


Fig. 2. The effects of the HO-1/ CO axis on poly-L-arginine- or nucleotide-induced cytokine release. a) Effect of HO-1 knockdown by siRNA. b) Summarized data showing the effects of HO-1 knockdown in both primary HBE and 16HBE140- cells. Each column represents the mean \pm S.E. $\left(n=3-5 ;{ }^{*}=p<0.05\right.$ compared with control group; $\#=p<0.05$ compared with mock-transfected group, one-way ANOVA with Tukey's post hoc test). c) and d) Effects of hemin $(10 \mu \mathrm{M})$, SnPP (1 $\mu \mathrm{M})$, haemoglobin $(\mathrm{Hb}, 50 \mu \mathrm{M})$ on PLA $(1 \mu \mathrm{M})-$, ATP $\gamma \mathrm{S}(10 \mu \mathrm{M})-$, or UTP $(100 \mu \mathrm{M})$-induced cytokine release. e) and f) Effects of HO-1 siRNA on PLA- or ATP $\gamma$ S-induced cytokine release in 16HBE140cells. g) and h) Effects of HO-1 siRNA on PLA- or ATP $\gamma$ S-induced cytokine release in primary HBE cells. Each column represents the mean \pm S.E. $(n=5-10 ; *=p<0.05$ compared with stimulators such as PLA, ATP $\gamma$ S, or UTP alone; \# = $\mathrm{p}<0.05$ compared with hemin + PLA or ATP $\gamma$; d different colours of * or \# indicates a within-group comparison, one-way ANOVA with Dunnett's post hoc test).

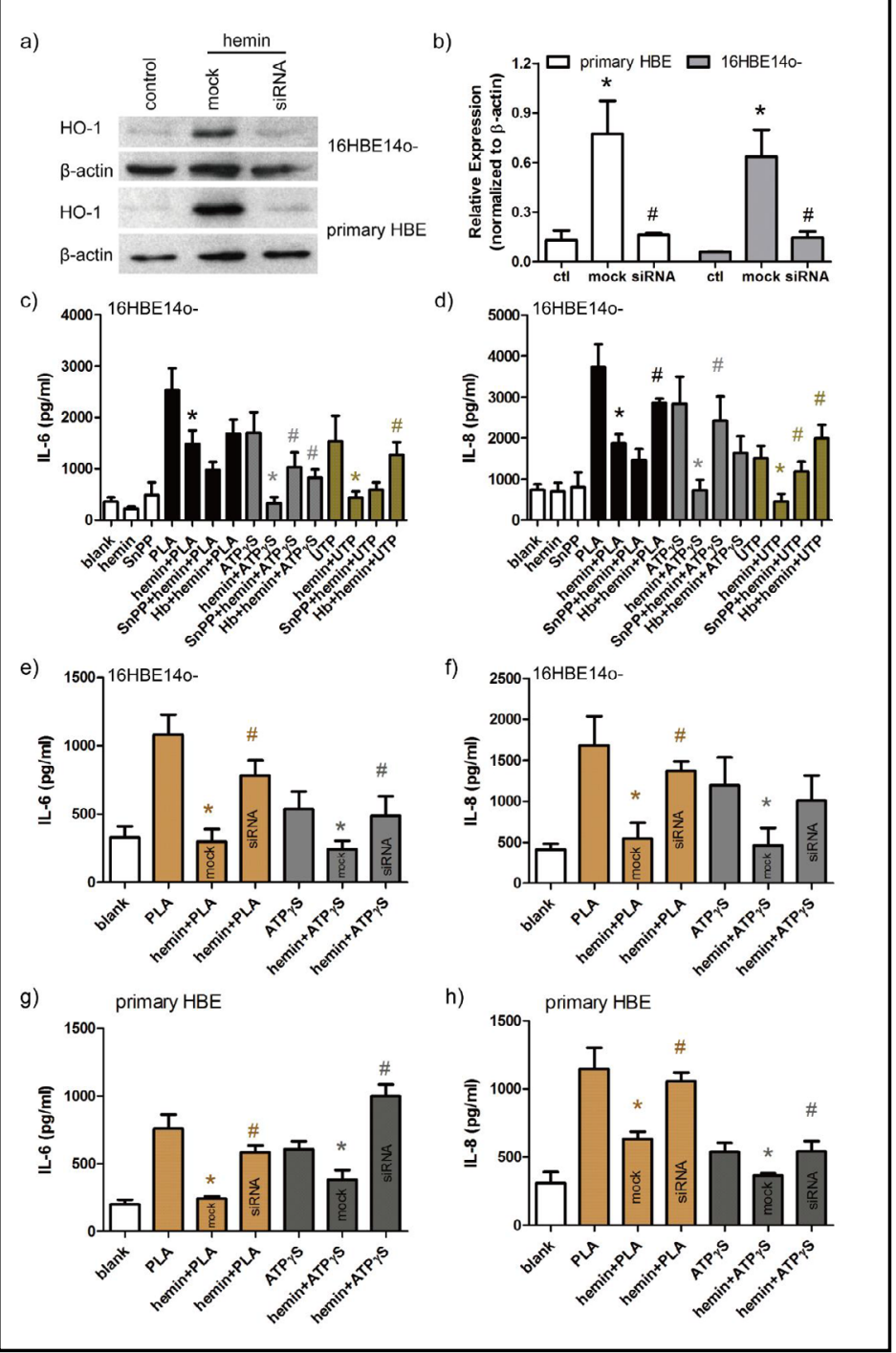

in both cells (primary HBE: $0.63 \pm 0.03$; 16 HBE140-: $0.91 \pm 0.08$ ), whereas HO- 1 was only weakly expressed in both primary HBE $(0.11 \pm 0.03)$ and 16 HBE14o- cells $(0.06 \pm 0.01)$ (Fig. $1 \mathrm{~b}$ and $1 \mathrm{~d}$ ). The Western blot results confirmed that HO-2 was the predominant isoform expressed at the basal level, although the mRNA and protein expression of HO-1 was induced by PLA or P2Y receptor activation by ATP $\gamma$ S. The percentage of HO-1 expression induced by PLA $(1 \mu \mathrm{M})$ or ATP $\gamma \mathrm{S}(10 \mu \mathrm{M})$ relative to that of hemin $(10 \mu \mathrm{M})$ was $41.4 \pm 10.6 \%$ and 23.9 $\pm 4.1 \%(\mathrm{n}=4)$, respectively.

\section{Anti-inflammatory effect of the HO-1/CO axis in HBE cells}

HO-1 induction reportedly exerts anti-inflammatory effects $[17,18]$. HO-1 expression was induced by hemin, a well-known HO-1 inducer [19], but reduced by siRNA (Fig. 2a). The anti-inflammatory effects of HO-1 induction on PLA- and nucleotide-induced IL- 6 and IL-8 release were quantified using ELISA. IL- 6 and IL-8 levels were significantly suppressed by hemin (Fig. 2b and 2c). The inhibitory effects of hemin were attenuated in the presence of SnPP, a HO-1 specific inhibitor [17, 18] , or haemoglobin, a CO scavenger [18]. (Fig. 2b and 2c). Furthermore, HO-1 siRNA knockdown abolished the inhibitory effect of hemin on IL-6 and IL-8 release in 16HBE14o- (Fig. $2 \mathrm{~d}$ and 2e) and primary HBE cells (Fig. 2f and 2g). In addition to inducing HO-1, hemin $(10 \mu \mathrm{M})$ also increased HO activity (4.99 \pm 1.04 -fold), which 


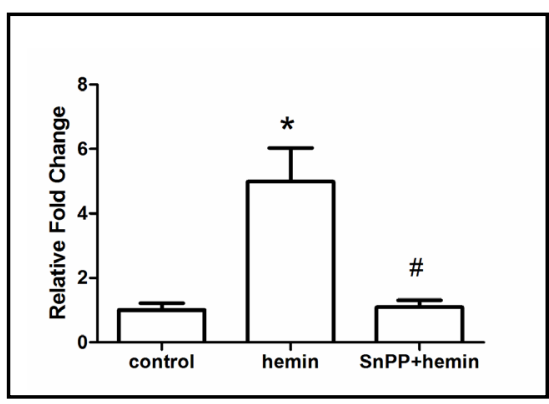

Fig. 3. HO activity was determined 6 hours after $10 \mu \mathrm{M}$ hemin treatment in the presence or absence of $1 \mu \mathrm{M}$ SnPP. Each bar represents the mean \pm S.E. ( $n$ $=4 ;^{*}=\mathrm{p}<0.05$ compared with control group; $\#=$ p $<0.05$ compared with hemin group, one-way ANOVA with Tukey's post hoc test).

was abolished in the presence of 1 $\mu \mathrm{M}$ SnPP $(1.09 \pm 0.22, n=4)$ (Fig. $3)$. These findings suggested an important anti-inflammatory role of endogenously produced $\mathrm{CO}$ in HBE cells.

Effect of CORM-3 on the ATP $\gamma$ Sinduced polarised release of IL-6 and IL-8 in 16HBE14ocells

To examine the anti-inflammatory effects of exogenously applied $\mathrm{CO}$ on the polarised secretion of IL-6 and IL-8 induced by P2Y receptor activation, 16HBE14o- cells were stimulated apically with ATP $\gamma \mathrm{S}$, a P2Y agonist, in the presence or absence of CORM-3. Fig. 4 shows that the apically directed basal release of IL-6 (a) and IL-8 (b) was $436.11 \pm 48.7$ and $321.17 \pm 38.71 \mathrm{pg} / \mathrm{ml}$, respectively. However, the basal IL- 6 (c) and IL-8 (d) levels at the basolateral side were higher $(1,233.33 \pm 274.22$ and $724.17 \pm 188.53 \mathrm{pg} / \mathrm{ml}$, respectively). ATP $\gamma$ S induced the apically directed secretion of IL-6 (Fig. 4a) and IL-8 (Fig. 4b). ATP $\gamma$ S did not induce IL-6 (Fig. 4c) and IL-8 (Fig. 4d) secretion at the basolateral compartment. Further, the ATP $\gamma$ S-induced apical release of IL-6 (Fig. 4a) and IL-8 (Fig. 4b) were significantly inhibited by CO. The basal level of basolateral IL-6 (Fig. 4c) and IL-8 (Fig. 4d) was also inhibited by CORM-3. IL- 6 and IL-8 levels in control or ATP $\gamma S$-stimulated cells $(n=6)$ were not affected by iCORM (negative control).

\section{Anti-inflammatory actions of CORM-3 in primary HBE cells}

The anti-inflammatory effects of CORM-3 were determined in primary HBE cells. PLA, ATP $\gamma$ S, and UTP markedly induced IL-6 and IL-8 levels, which were significantly suppressed by CORM-3 (Fig. 5a and b). Additionally, PLA increased the phosphorylation of ERK1/2 MAPK (Fig. 5c) and p65 NF-kB (Fig. 5d), which were suppressed by CORM-3. Similar data were obtained in 16HBE140- cells (data not shown).

Inhibitory effect of CORMS on cAMP-dependent $I_{S C}$

CFTR is an essential ion channel activated by cAMP/PKA signalling pathway that mediates anion secretion in airway epithelial cells [20]. To study the effect of CO on CFTRmediated chloride $\left(\mathrm{Cl}^{-}\right)$secretion, forskolin, an adenylate cyclase activator, was used to 
Fig. 5. The anti-inflammatory action of CORM-3 in primary HBE cells. a) and b) Primary cells were pre-treated with CORM-3 for 30 min and then stimulated with PLA $(1 \mu \mathrm{M})$, ATP $\gamma \mathrm{S}(10 \mu \mathrm{M})$, or UTP $(100 \mu \mathrm{M})$ for 3 hours in the presence of CORM-3. The secretion of IL-6 a) and IL-8 b) was examined by ELISA. Each column represents the mean \pm S.E. $\left(n=4-8 ;^{*}=p<0.05\right.$ compared with the PLA-, ATP $\gamma \mathrm{S}-$-, or UTP-treated groups; different colours of $*$ indicates a withingroup comparison, one-way ANOVA with Dunnett's post hoc test). c) and d) Effects of CORM-3 $(100 \mu \mathrm{M})$ on PLA $(1 \mu \mathrm{M})$-induced ERK1/2 or p65 phosphorylation. Primary cells were pre-treated with CORM-3 for $30 \mathrm{~min}$ and then stimulated with PLA $(1 \mu \mathrm{M})$ for the indicated time points in the presence of CORM-3. Each column represents the mean \pm S.E. $\left(n=4-5 ;{ }^{*}=p<0.05\right.$ compared with control group, one-way ANOVA with Dunnett's post hoc test).

Fig. 6. The simultaneous measurement of real-time cAMP and $\mathrm{I}_{\mathrm{SC}}$ in the $16 \mathrm{HBE} 14 \mathrm{o}$ - epithelial monolayer. a) Increases in cAMP levels and $\mathrm{I}_{\mathrm{SC}}$ were induced by the apical application of forskolin $(10 \mu \mathrm{M})$ in control (black) or 100 $\mu \mathrm{M}$ CORM-3- treated epithelia (red). The epithelium was initially perfused with $\mathrm{KH}$ solution while changes in $\mathrm{I}_{\mathrm{SC}}$ (upper trace; left $y$-axis) and cAMP levels (lower

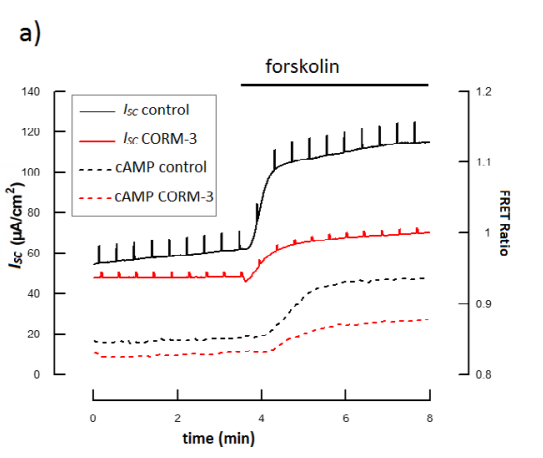

b)

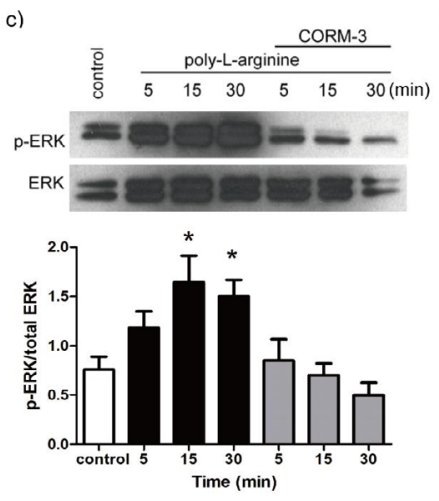

d)
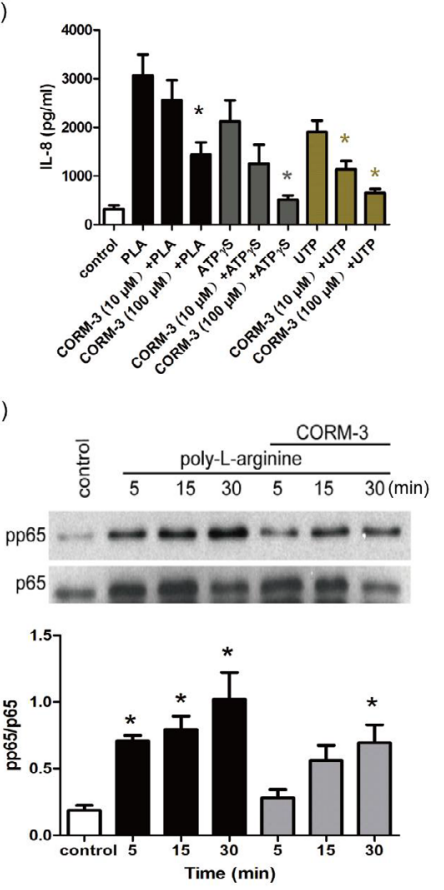

trace; FRET ratio; right $\mathrm{y}$-axis)

were recorded simultaneously. As described in the MATERIALS AND METHODS, a serosal-to-mucosaldirected $\mathrm{Cl}^{-}$gradient was applied across the monolayers (not shown in the graph). Transient current pulses were a result of clamping the potential intermittently at $1 \mathrm{mV}$. Comparable responses were observed in at least six independent replicates. b) Summarised data showing the effect of CO released from CORM-2 (100 $\mu \mathrm{M})$ or CORM-3 $(100 \mu \mathrm{M})$ on forskolin-induced cAMP and $\mathrm{I}_{\mathrm{SC}}$. Each column represents the mean \pm S.E. $(\mathrm{n}=$ $6-10 ;{ }^{*}=\mathrm{p}<0.05$ compared with control, one-way ANOVA with Dunnett's post hoc test).

induce cAMP/PKA signalling [21]. The forskolin-induced increase in cAMP and subsequent increase in $I_{S C}$ was inhibited by CORM-3 (Fig. 6a). CORM-2 and CORM-3 also had an inhibitory effect on the increase in cAMP and $I_{S C}$ (Fig. 6b). iCORM had no inhibitory effect on forskolininduced increases in the FRET ratio (control, change in ratio $=0.11 \pm 0.01$; iCORM, change in ratio $=0.09 \pm 0.01 ; \mathrm{p}>0.05, n=4-7)$ and $I_{S C}$ (control, change in $I_{S C}=29.4 \pm 2.2 \mu \mathrm{Acm}^{-2} ; \mathrm{iCORM}$ 
Fig. 7. Detection of CO released from CORMs and $\mathrm{CO}$ quantification of CO-bubbled low-Cl- KHS. (A) Absorption spectrum of deoxymyoglobin and COcontaining deoxymyoglobin (MbCO) with or without CORM-3. Deoxymyoglobin was converted to $\approx 100 \%$ MbCO after bubbling the myoglobin solution for $1 \mathrm{~min}$ with $\mathrm{CO}$ gas and act as saturate. (B) and (C) Determination of the amount of MbCO formed after adding CORM-3 (B) and KHS (C). (D) The summarized data showing the concentration of $\mathrm{CO}$ contained in CO-bubbled low-Cl- ${ }^{-} \mathrm{KHS}$ (4 fold dilution) and the concentration of CO released from $100 \mu$ M CORM-2 or CORM-3. ( $=5)$.
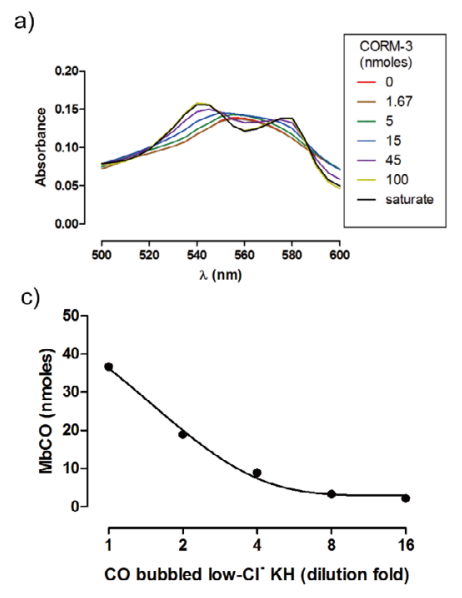

d)
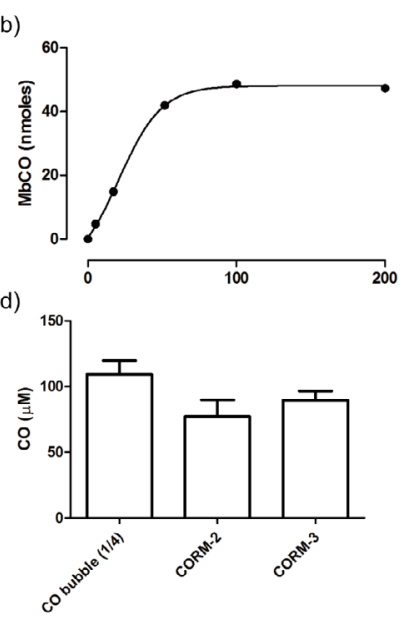

Fig. 8. The simultaneous measurement of $\left[\mathrm{Ca}^{2+}\right]_{\mathrm{i}}$ and $\mathrm{I}_{\mathrm{SC}}$ in the 16HBE140- epithelial monolayer. a) Increases in $\left[\mathrm{Ca}^{2+}\right]_{i}$ and $\mathrm{I}_{\mathrm{SC}}$ were induced by the apical application of UTP $(100 \mu \mathrm{M})$ in control (black) or CO-treated ( $1 \times$ dilution) epithelia (red). The epithelium was initially perfused with $\mathrm{KH}$ solution while changes in the $\mathrm{I}_{\mathrm{SC}}$ (upper trace; left y-axis) and Fura2 ratio (lower trace; right $\mathrm{y}$-axis) were recorded simultaneously. As

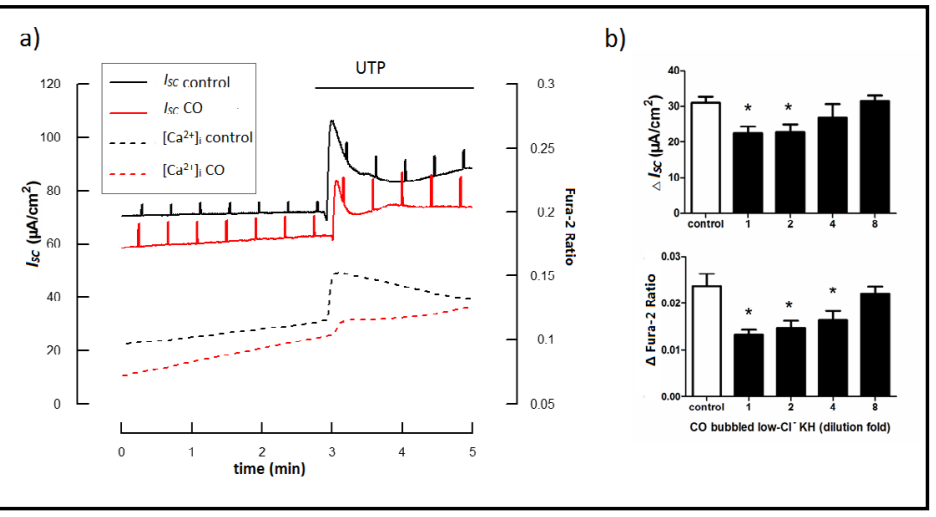
described in the MATERIALS AND METHODS, a serosal-to-mucosal-directed $\mathrm{Cl}^{-}$gradient was applied across the monolayers (not shown in the graph). Transient current pulses were a result of clamping the potential intermittently at $1 \mathrm{mV}$. Comparable responses were observed in at least six independent replicates. b) Summarised data showing the concentration-dependent inhibitory effect of CO on UTP-induced $\left[\mathrm{Ca}^{2+}\right]_{\mathrm{i}}$ and $\mathrm{I}_{\mathrm{SC}}$. Each column represents the mean \pm S.E. $\left(n=9-12 ;{ }^{*}=p<0.05\right.$ compared with control, one-way ANOVA with Dunnett's post hoc test).

change in $\left.I_{S C}=28.2 \pm 2.2 \mu \mathrm{Acm}^{-2} ; \mathrm{p}>0.05, n=4-7\right)$. Consistent with previous studies, data from a myoglobin assay indicated that 77.06 and $89.46 \mu \mathrm{M}$ CO was released from $100 \mu \mathrm{M}$ CORM-2 and CORM-3, respectively (Fig. 7) [14, 22].

Inhibitory effect of CO on UTP-induced $\left[\mathrm{Ca}^{2+}\right]_{i}$ and $\mathrm{I}_{S C}$ increase

To examine the effect of $\mathrm{CO}$ on $\mathrm{Ca}^{2+}$-dependent $\mathrm{Cl}^{-}$secretion in the polarised 16HBE14omonolayer, the UTP-induced $\left[\mathrm{Ca}^{2+}\right]_{\mathrm{i}}$ and $I_{S C}$ were measured simultaneously. In the presence of $100 \mu \mathrm{M}$ CORM-3, $100 \mu \mathrm{M}$ UTP-induced [ $\left.\mathrm{Ca}^{2+}\right]_{\mathrm{i}}$ and $I_{S C}$ were significantly inhibited (Control, change in ratio $=0.052 \pm 0.007 ; \mathrm{CORM}-3$ change in ratio $=0.032 \pm 0.003 ; \mathrm{p}<0.05 ; \mathrm{n}=8$ and Control, change in $I_{S C}=26.79 \pm 1.73 \mu \mathrm{Acm}^{-2}$; CORM-3, change in $I_{S C}=12.45 \pm 2.14 \mu \mathrm{Acm}^{-2} ; \mathrm{p}<$ $0.05 ; n=8$ ). To confirm the effect of CORM-3 was due to CO, the monolayer was stimulated with UTP $(100 \mu \mathrm{M})$ in the presence or absence of different concentrations of CO-containing $\mathrm{KH}$ solution (Fig. 8a). The concentrations of $\mathrm{CO}$ in non-diluted (1-fold) and diluted (2, 4, 8-fold) CO-containing $\mathrm{KH}$ solution were 506.71 $\pm 23.17,207.31 \pm 20.17,109.18 \pm 11.1$, and $51.83 \pm 5.04 \mu \mathrm{M}$, respectively, as determined by a myoglobin assay (Fig. 7). Both $\left[\mathrm{Ca}^{2+}\right]_{\mathrm{i}}$ and $I_{S C}$ 
(Fig. 8b) were inhibited by the CO-containing solution in a concentration-dependent manner. To determine the direct effect of $\mathrm{CO}$ on calcium-activated $\mathrm{Cl}^{-}$channels (CaCC), the specific CaCC activator, Eact [23], was used. However, CO did not inhibit Eact-induced $I_{S C}(n=3$, data not shown), suggesting that CO may interact upstream of the calcium signalling pathway.

\section{Discussion}

The results of this study are the first to reveal that CO efficiently inhibited proinflammatory cytokine release induced by bronchial epithelial damage, extracellular nucleotides, and calcium- and cAMP-activated $\mathrm{Cl}^{-}$secretion, and provide a novel strategy to alleviate airway inflammatory diseases by targeting purinergic signalling pathways.

In both primary HBE and 16HBE140- cells, CO endogenously produced by HO-1 or released by CORMs exhibited strong anti-inflammatory potential via interactions with purinergic signalling. The HO-1/CO axis reportedly serves as a protective mechanism against inflammation and cell stress [24, 25]. However, the effect of $\mathrm{CO}$ on airway inflammation, especially the interaction between $\mathrm{CO}$ and purinergic signalling, remains unclear. Our results indicate that CO suppresses the release of the pro-inflammatory cytokines IL- 6 and IL-8, which are secreted in response to cellular damage by PLA [8] or P2Y receptor activation via p38, ERK1/2 MAPK, or NF- $\kappa B$ signalling [7]. CO inhibited p65 NF- $\kappa$ B and ERK1/2 phosphorylation, but not $\mathrm{p} 38$, suggesting the anti-inflammatory effect of $\mathrm{CO}$ is mediated via the inhibition of these two signalling pathways. This result is similar to a study in human airway smooth muscle cells in which $\mathrm{CO}$ also inhibited ERK1/2 but not the p38 MAPK pathway [26]. Purinergic receptor agonists, such as ATP and UTP, are known to activate the calcium signalling pathway [27]. Previously, we reported that extracellular nucleotideinduced pro-inflammatory cytokines release is calcium-dependent [7] and that CO can inhibit P2Y receptor-mediated $\mathrm{Ca}^{2+}$ signalling pathway in 16HBE14o- cells [28]. Results from the present study further confirm the inhibitory effect of $\mathrm{CO}$ on $\mathrm{P} 2 \mathrm{Y}$ receptor-mediated $\mathrm{Ca}^{2+}$ signalling pathway, which underlies the anti-inflammatory action of $\mathrm{CO}$ in human bronchial epithelia.

Although PLA and ATP $\gamma \mathrm{S}$ induced the expression of HO-1, the stimulation of both could still trigger the release of IL- 6 and IL-8. Therefore, our data suggest that this protective antiinflammatory mechanism was not sufficient to completely block the pro-inflammatory effect induced by PLA treatment or P2Y receptor activation by ATP $\gamma$ S. Hemin, a potent inducer of HO-1, caused a much larger increase in HO-1 expression than PLA or ATP $\gamma$ S, which may have further reduced the release of IL- 6 and IL-8. The effect of hemin was not attenuated by SnPP or Hb under any experimental conditions. This inconsistency typically appeared in the PLAtreated groups and might be due the same reason the pro-inflammatory effects of PLA are not entirely the result of P2Y receptor activation. However, the underlying reasons are not yet understood and require further investigation. In contrast, the nucleotide-treated groups exhibited good attenuation by SnPP or $\mathrm{Hb}$. As well, using a siRNA approach to knockdown HO-1 consistently demonstrated the anti-inflammatory role of HO-1 upregulation in both the PLA- and nucleotide-treated groups. Taken together, our data suggest that HO-1 plays an important role in inhibiting IL- 6 and IL-8 release in the inflamed epithelia.

In the current study, CO inhibited UTP-induced calcium increases and concomitant increases in $I_{S C}$ in 16HBE140- cells. Calcium signal inhibition began after the use of a fourfold diluted CO-containing solution, in which the actual CO concentration was similar to 100 $\mu \mathrm{M}$ CORMs. Previously, we demonstrated that the nucleotide-stimulated $I_{S C}$ was due to $\mathrm{Cl}^{-}$ secretion via apical CaCC [29]. The inhibitory effect of $\mathrm{CO}$ on $\mathrm{Ca}^{2+}$-dependent $I_{S C}$ is likely due to its lowering effect on $\left[\mathrm{Ca}^{2+}\right]_{\mathrm{i}}$ since $\mathrm{CO}$ has no effect on $I_{S C}$ mediated by Eact-activated CaCC. Activation of the basolateral $\mathrm{Ca}^{2+}$-dependent $\mathrm{K}^{+}$channel would drive the apical exit of $\mathrm{Cl}^{-}$in $16 \mathrm{HBE} 14 \mathrm{o}$ - cells [9], but $\mathrm{CO}$ did not affect $I_{S C}$ activated by 1 -EBIO, a $\mathrm{Ca}^{2+}$-dependent $\mathrm{K}^{+}$channel activator [30]. Moreover, we previously demonstrated that CO specifically suppressed P2Y receptor-mediated calcium signalling without affecting store-operated calcium entry [28]. It

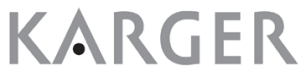


is possible that $\mathrm{CO}$ inhibits both $\mathrm{IP}_{3}$-dependent $\mathrm{Ca}^{2+}$ release and receptor-operated calcium entry [28]. Because UTP activates CFTR via $\mathrm{Ca}^{2+} /$ calmodulin-stimulated adenylyl cyclase in HBE cells [31] and CO inhibited the forskolin-induced cAMP increase, it is possible that the inhibition of $\mathrm{Ca}^{2+}$-dependent $I_{S C}$ by $\mathrm{CO}$ may be partially due to its inhibitory effect on cAMP formation. Nonetheless, these findings reveal a novel regulatory role of $\mathrm{CO}$ on purinergic signalling pathways and ion transport in airway epithelia.

Further, the results from the simultaneous measurements indicated that $\mathrm{CO}$ plays an inhibitory role in cAMP-activated $\mathrm{Cl}^{-}$secretion in airway epithelial cells. The inhibitory action of $\mathrm{CO}$ on forskolin-induced $\mathrm{Cl}^{-}$secretion was unexpected. The results revealed, for the first time, that $\mathrm{CO}$ could directly suppress cAMP formation, which is the most likely reason underlying its inhibitory effect on forskolin-induced $I_{S C}$. CO had no effect on $I_{S C}$ activated by L-364, 373, an activator of cAMP-dependent $\mathrm{K}^{+}$channels [32]. The molecular mechanism underlying the inhibitory effect of $\mathrm{CO}$ on cAMP formation requires further investigation. However, an interesting study by Turner et al. demonstrated that $\mathrm{CO}_{2}$ inhibited CFTRdependent anion and fluid transport in Calu-3 cells, possibly by inhibiting agonist-stimulated cAMP levels via effects on transmembrane adenylate cyclase activity [33].

Intracellular $\mathrm{Ca}^{2+}$ concentration and cAMP are the two major signal transduction cascades involved in regulating airway ion transport; thus, the inhibitory actions of $\mathrm{CO}$ on $\mathrm{Ca}^{2+}$ - and cAMP-dependent $I_{S C}$ suggest that CO might play a significant role in modulating ion transport in human airway epithelia. Nucleotide release also affects the modulation of ASL [34]. The maintenance of a proper ASL volume is essential to respiratory physiology and mucociliary clearance. A pro-secretory epithelial ion transport phenotype can be induced in mice by allergic airway inflammation [3]. Therefore, although CO exhibits an anti-inflammatory effect, inhibition of ion transport by $\mathrm{CO}$ might not be beneficial as it could hinder airway surface hydration and mucus clearance. However, in certain lung diseases involving impaired gaseous exchange, the inhibition of ion transport might prevent further aggravation of the symptoms [6]. Nucleotide release is associated with inflammatory conditions including asthmatic inflammation [2] and neutrophil migration [35] and activation [36]. Upregulation of extracellular ATP also reportedly contributes to COPD pathogenesis by promoting inflammation and tissue degradation [37]. A pilot study on COPD revealed a trend in reduced sputum eosinophil percentage and improved responsiveness to methacholine following inhaled CO [38]. Therefore, our findings could lead to further therapeutic applications of CO or CORMs in the treatment of airway inflammation by targeting purinergic receptors.

In summary, our study revealed a regulatory role of $\mathrm{CO}$ on nucleotide-induced airway epithelial inflammation and $\mathrm{Cl}^{-}$secretion. In 16HBE140- and primary HBE cells, CO exhibited inhibitory effects on IL- 6 and IL-8 release, as well as p65 NF- $\mathrm{kB}$ and ERK1/2 phosphorylation. Furthermore, to the best of our knowledge, this is the first study to demonstrate an inhibitory role of $\mathrm{CO}$ on calcium- and cAMP-activated $\mathrm{Cl}^{-}$secretion. Our study revealed a novel modulatory role of $\mathrm{CO}$ in two important aspects of airway epithelial physiology, namely immune response and transepithelial ion transport, via interactions with purinergic signalling pathways. Hence, this study provides mechanistic support for the development of $\mathrm{CO}$ as an anti-inflammatory agent in airway inflammatory diseases.

\section{Acknowledgements}

This work was supported by the Research Grant Council General Research Fund (\#466913) awarded to W.H. Ko. We thank Dr. D.C.Gruenert (Burlington, Vermont, USA) for the generous gift of the 16HBE14o- cells. 


\section{Cellular Physiology Cell Physiol Biochem 2018;49:626-637 \begin{tabular}{ll|l} 
and Biochemistry Published online: 30 August, 2018 & $\begin{array}{l}\text { (c) } 2018 \text { The Author(s). Published by S. Karger AG, Basel } \\
\text { www.karger.com/cpb }\end{array}$ \\
\hline
\end{tabular}}

Zhang et al.: $\mathrm{CO}$ and Airway Secretion

\section{Disclosure Statement}

The authors declare that they have no conflicts of interest with the contents of this article.

\section{References}

1 Idzko M, Ferrari D, Eltzschig HK: Nucleotide signalling during inflammation. Nature 2014;509:310-317.

-2 Idzko M, Hammad H, van Nimwegen M, Kool M, Willart MA, Muskens F, Hoogsteden HC, Luttmann W, Ferrari D, Di Virgilio F, Virchow JC Jr, Lambrecht BN: Extracellular ATP triggers and maintains asthmatic airway inflammation by activating dendritic cells. Nat Med 2007;13:913-919.

- 3 Anagnostopoulou P, Dai L, Schatterny J, Hirtz S, Duerr J, Mall MA: Allergic airway inflammation induces a pro-secretory epithelial ion transport phenotype in mice. Eur Respir J 2010;36:1436-1447.

4 Danahay H, Atherton H, Jones G, Bridges RJ, Poll CT: Interleukin-13 induces a hypersecretory ion transport phenotype in human bronchial epithelial cells. Am J Physiol Lung Cell Mol Physiol 2002;282:L226-236.

5 Galietta LJ, Pagesy P, Folli C, Caci E, Romio L, Costes B, Nicolis E, Cabrini G, Goossens M, Ravazzolo R, Zegarra-Moran O: IL-4 is a potent modulator of ion transport in the human bronchial epithelium in vitro. J Immunol 2002;168:839-845.

6 Hug MJ: CO2 - friend or foe? J Physiol 2016;594:1521.

7 Hao Y, Liang JF, Chow AW, Cheung WT, Ko WH: P2Y receptor-mediated proinflammatory signaling in human bronchial epithelia. PLoS One 2014;9:e106235.

-8 Chow AW, Liang JF, Wong JS, Fu Y, Tang NL, Ko WH: Polarized secretion of interleukin (IL)-6 and IL-8 by human airway epithelia 16HBE14o- cells in response to cationic polypeptide challenge. PLoS One 2010;5:e12091.

-9 Wong AM, Chow AW, Au SC, Wong CC, Ko WH: Apical versus basolateral P2Y receptor-mediated $\mathrm{Cl}^{-}$ secretion in immortalized bronchial epithelia. Am J Respir Cell Mol Biol 2009;40:733-745.

10 Hao Y, Chow AW, Yip WC, Li CH, Wan TF, Tong BC, Cheung KH, Chan WY, Chen Y, Cheng CH, Ko WH: G protein-coupled estrogen receptor inhibits the $\mathrm{P} 2 \mathrm{Y}$ receptor-mediated $\mathrm{Ca}^{2+}$ signaling pathway in human airway epithelia. Pflugers Arch 2016;468:1489-1503.

11 Lanceta L, Mattingly JM, Li C, Eaton JW: How Heme Oxygenase-1 Prevents Heme-Induced Cell Death. PLoS One 2015;10:e0134144.

12 Cozens AL, Yezzi MJ, Kunzelmann K, Ohrui T, Chin L, Eng K, Finkbeiner WE, Widdicombe JH, Gruenert DC: CFTR expression and chloride secretion in polarized immortal human bronchial epithelial cells. Am J Respir Cell Mol Biol 1994;10:38-47.

13 Almeida AS, Queiroga CS, Sousa MF, Alves PM, Vieira HL: Carbon monoxide modulates apoptosis by reinforcing oxidative metabolism in astrocytes: role of Bcl-2. J Biol Chem 2012;287:10761-10770.

14 Motterlini R, Clark JE, Foresti R, Sarathchandra P, Mann BE, Green CJ: Carbon monoxide-releasing molecules: characterization of biochemical and vascular activities. Circ Res 2002;90:E17-24.

-15 Choi BM, Kim YM, Jeong YR, Pae HO, Song CE, Park JE, Ahn YK, Chung HT: Induction of heme oxygenase-1 is involved in anti-proliferative effects of paclitaxel on rat vascular smooth muscle cells. Biochem Biophys Res Commun 2004;321:132-137.

-16 Donnelly LE, Barnes PJ: Expression of heme oxygenase in human airway epithelial cells. Am J Respir Cell Mol Biol 2001;24:295-303.

$\checkmark 17$ Konrad FM, Braun S, Ngamsri KC, Vollmer I, Reutershan J: Heme oxygenase-1 attenuates acute pulmonary inflammation by decreasing the release of segmented neutrophils from the bone marrow. Am J Physiol Lung Cell Mol Physiol 2014;307:L707-717.

18 Ryter SW, Choi AM: Targeting heme oxygenase-1 and carbon monoxide for therapeutic modulation of inflammation. Transl Res 2016;167:7-34.

19 Botros FT, Prieto-Carrasquero MC, Martin VL, Navar LG: Heme oxygenase induction attenuates afferent arteriolar autoregulatory responses. Am J Physiol Renal Physiol 2008;295:F904-911.

20 Haq IJ, Gray MA, Garnett JP, Ward C, Brodlie M: Airway surface liquid homeostasis in cystic fibrosis: pathophysiology and therapeutic targets. Thorax 2016;71:284-287. 


\section{Cellular Physiology Cell Physiol Biochem 2018;49:626-637 \begin{tabular}{l|l} 
DOI: 10.1159/000493026 & $\begin{array}{l}\text { O 2018 The Author(s). Published by S. Karger AG, Basel } \\
\text { wwww.karger.com/cpb }\end{array}$
\end{tabular}

Zhang et al.: $\mathrm{CO}$ and Airway Secretion

-21 Fan S, Harfoot N, Bartolo RC, Butt AG: CFTR is restricted to a small population of high expresser cells that provide a forskolin-sensitive transepithelial $\mathrm{Cl}^{-}$conductance in the proximal colon of the possum, Trichosurus vulpecula. J Exp Biol 2012;215:1218-1230.

22 Motterlini R, Mann BE, Foresti R: Therapeutic applications of carbon monoxide-releasing molecules. Expert Opin Investig Drugs 2005;14:1305-1318.

-23 Namkung W, Yao Z, Finkbeiner WE, Verkman AS: Small-molecule activators of TMEM16A, a calciumactivated chloride channel, stimulate epithelial chloride secretion and intestinal contraction. FASEB J 2011;25:4048-4062.

-24 Ryter SW, Alam J, Choi AM: Heme oxygenase-1/carbon monoxide: from basic science to therapeutic applications. Physiol Rev 2006;86:583-650.

-25 Otterbein LE, Choi AM: Heme oxygenase: colors of defense against cellular stress. Am J Physiol Lung Cell Mol Physiol 2000;279:L1029-1037.

-26 Song R, Ning W, Liu F, Ameredes BT, Calhoun WJ, Otterbein LE, Choi AM: Regulation of IL-1beta -induced GM-CSF production in human airway smooth muscle cells by carbon monoxide. Am J Physiol Lung Cell Mol Physiol 2003;284:L50-56.

27 Abbracchio MP, Burnstock G, Boeynaems JM, Barnard EA, Boyer JL, Kennedy C, Knight GE, Fumagalli M, Gachet C, Jacobson KA, Weisman GA: International Union of Pharmacology LVIII: update on the P2Y G protein-coupled nucleotide receptors: from molecular mechanisms and pathophysiology to therapy. Pharmacol Rev 2006;58:281-341.

-28 Zhang RG, Yip CY, Ko WH: Regulation of Intracellular Calcium by Carbon Monoxide in Human Bronchial Epithelial Cells. Cell Physiol Biochem 2017;42:2377-2390.

-29 Wong CH, Ko WH: Stimulation of $\mathrm{Cl}^{-}$secretion via membrane-restricted $\mathrm{Ca}^{2+}$ signaling mediated by P2Y receptors in polarized epithelia. J Biol Chem 2002;277:9016-9021.

-30 Hug MJ, Tamada T, Bridges RJ: CFTR and bicarbonate secretion by [correction of to] epithelial cells. News Physiol Sci 2003;18:38-42.

-31 Namkung W, Finkbeiner WE, Verkman AS: CFTR-adenylyl cyclase I association responsible for UTP activation of CFTR in well-differentiated primary human bronchial cell cultures. Mol Biol Cell 2010;21:2639-2648.

32 Salata JJ, Jurkiewicz NK, Wang J, Evans BE, Orme HT, Sanguinetti MC: A novel benzodiazepine that activates cardiac slow delayed rectifier K+ currents. Mol Pharmacol 1998;54:220-230.

-33 Turner MJ, Saint-Criq V, Patel W, Ibrahim SH, Verdon B, Ward C, Garnett JP, Tarran R, Cann MJ, Gray MA: Hypercapnia modulates cAMP signalling and cystic fibrosis transmembrane conductance regulatordependent anion and fluid secretion in airway epithelia. J Physiol 2016;594:1643-1661.

34 Lazarowski ER, Tarran R, Grubb BR, van Heusden CA, Okada S, Boucher RC: Nucleotide release provides a mechanism for airway surface liquid homeostasis. J Biol Chem 2004;279:36855-36864.

-35 Chen Y, Corriden R, Inoue Y, Yip L, Hashiguchi N, Zinkernagel A, Nizet V, Insel PA, Junger WG: ATP release guides neutrophil chemotaxis via P2Y2 and A3 receptors. Science 2006;314:1792-1795.

-36 Chen Y, Yao Y, Sumi Y, Li A, To UK, Elkhal A, Inoue Y, Woehrle T, Zhang Q, Hauser C, Junger WG: Purinergic signaling: a fundamental mechanism in neutrophil activation. Sci Signal 2010;3:ra45.

-37 Lommatzsch M, Cicko S, Muller T, Lucattelli M, Bratke K, Stoll P, Grimm M, Durk T, Zissel G, Ferrari D, Di Virgilio F, Sorichter S, Lungarella G, Virchow JC, Idzko M: Extracellular adenosine triphosphate and chronic obstructive pulmonary disease. Am J Respir Crit Care Med 2010;181:928-934.

-38 Bathoorn E, Slebos DJ, Postma DS, Koeter GH, van Oosterhout AJ, van der Toorn M, Boezen HM, Kerstjens HA: Anti-inflammatory effects of inhaled carbon monoxide in patients with COPD: a pilot study. Eur Respir J 2007;30:1131-1137. 